the orthodox aeroplane aileron, elevator and rudder for lateral, horizontal, and directional control respectively. This new model, Type C.30, replaces all of these controls by altering the direction of the resultant lift of the rotors by tilting their supporting pillar. A lever attached to this column is pulled back to make the nose rise, forward to drop, sideways to turn and bank correctly at the same time. Thus the pilot's task in the air is considerably simplified, although apparently at the expense of a certain amount of rapidity in manceuvrability. Another advantage of this new control is that its effectiveness is a function of the speed of the rotating blades, and not of the forward speed of the machine as in the normal aircraft. It is therefore equally effective at low flying speeds, a particularly important point in landing, taking off, and flying near the ground generally. The absence of the usual control surfaces and their supporting parts should give a considerable saving in both weight and head resistance, and should simplify construction. A fixed tail plane and a vertical fin are still retained for stability, and a tail wheel controlled by an orthodox rudder bar is used for turning on the ground.

\section{Royal Institution}

THE annual meeting of the members of the Royal Institution was held on May 1, the president, Lord Eustace Percy, being in the chair. The annual report of the Visitors for the year ended December 31, 1932, testified to a year of considerable activity. The membership had been well maintained. The privilege of free attendance at the afternoon lectures by bona fide students in London had been much appreciated and used. The report on the progress of the researches in the Davy Faraday Laboratory gave a good indication of the considerable extent of the research organisation which is at work under the direction of Sir William Bragg. Some sixteen or eighteen workers are engaged, the majority on problems related to the $\mathrm{X}$-ray determination of structure. Mention was made of Dr. J. M. Robertson's determination of the structure of anthracene, of Dr. A. Müller's work on the long-chain compounds, and of the growth in accuracy and capacity of the large experimental X-ray plant in the hands of Dr. Müller and Mr. R. S. Clay. The capacity of the apparatus is calculated to be about $50 \mathrm{kw}$.; as yet it has worked well up to $10 \mathrm{kw}$. The treasurer's report and accounts showed a very satisfactory position, in spite of the heavy demand on the financial resources of the Institution caused by the recent reconstruction. After a total expenditure in connexion with the rebuilding of more than $£ 100,000$, a diminution in the invested funds of the Royal Institution of about $£ 2,000$ is shown. This gratifying result is a consequence of many generous donations to the Building and Research Endowment Fund raised by the Institution in the past three years. The donations and other receipts to this fund have been sufficient to defray almost the entire cost of the rebuilding, and to go a considerable way towards completion of the programme of permuanent endowment of research which the Managers of the Institution have as one of their principal objects. The following officers for 1933-34 were elected: President, the Right Hon. Lord Eustace Percy; Treasurer, Sir Robert Robertson; Secretary, Major Charles E. S. Phillips.

\section{Portrait of Sir William Bragg, K.B.E., O.M., F.R.S.}

AFTER the formal business of the annual meeting of the members of the Royal Institution, a portrait of Sir William Bragg, painted by Mr. William Nicholson, was presented to the Institution, on behalf of a group of subscribers, by the honorary secretary, Major Charles E. S. Phillips, who expressed the gratification of the donors at having secured the help of so distinguished an artist. Mr. Nicholson had given them, he said, not only a good portrait of Sir William, but also a very fine painting. Major Phillips went on to pay a tribute of admiration for the work of Sir William Bragg and to speak of the affection in which he is held by the members and all others with whom he comes into contact in his work. The portrait was accepted by the president, who thanked Major Phillips for having taken the initiative in regard to its painting and presentation, resulting in a valuable acquisition to the permanent treasures of the Institution. Sir William Bragg spoke briefly of his own pleasure at the expressions of goodwill with which the presentation had been made, and said that the success of the work of the Royal Institution was largely due to the friendship and devotion of its members, who had always responded freely to any request for services or appeal for help.

\section{Centenary of Hancock's Steam Omnibus}

To commemorate the centenary of the inauguration of the first power-driven omnibus in London, a joint meeting of the Newcomen Society and the Omnibus Society was held at the Institute of Marine Engineers on April 27 at which papers were read by Mr. C. E. Lee and Mr. C. F. D. Marshall. Mr. Lee said that the three principal pioneers of the steam omnibus were Goldsworthy Gurney (1793-1875), Walter Hancock (1799-1852) and John Scott Russell (1808-1882), of whom Hancock was the most successful. A watchmaker by trade, Hancock patented a very ingenious type of boiler and then built two steam carriages, the second of which, called the Infant, in February, 1831, began running between Stratford and London. Two years later, the London and Paddington StreamCarriage Co. was formed and for this Hancock built the omnibus Enterprise with accommodation for fourteen passengers. This vehicle began running between Moorgate and Paddington on April 22, 1833, and was the first mechanically propelled vehicle specially designed for omnibus work ever to be placed in service. The route covered was about ten miles and the distance was performed in about fifty minutes. The service was worked for 16 days only, under the superintendence of Hancock, and was then withdrawn owing to differences between him and the Company. Three years later, after other experimental work, Hancock had other steam vehicles at work and 
in the course of twenty weeks these ran 4,200 miles and carried 12,761 passengers. Both the papers contained much information on the construction of these and other early steam omnibuses and it cannot be doubted that if the inventions had been fostered, instead of hindered, by legislation, the steam vehicle would have been brought to a high degree of perfection at an early date.

\section{Observational and Theoretical Astronomy}

ON April 28, Prof. H. H. Plaskett delivered his inaugural lecture as Savilian professor of astronomy at Oxford. Recalling the fact that the year of the foundation of the professorship was also that of the publication of Kepler's three laws of planetary motion, and directing attention to the injunction of Sir Henry Savile that the holder of his professorship should occupy himself with "observation by day and night", he remarked that three hundred years ago the observational method in astronomy might be said to have reached its zenith. Since then, the constantly increasing importance of the theoretical method has been abundantly shown; as, for example, in the discovery of Neptune by calculation and in the present conclusions as to the physical conditions in the interior of stars. Nevertheless, the achievements of theoretical astronomy still rest in part on an observational basis. This is shown by consideration of the means by which knowledge of the spatial distribution of the stars has been gained by the work of Herschel and Shapley, and of that of their physical constitution by the work of Lockyer, Franklin and Hertzsprung. It would be fair to say, looking forward to the next three or four hundred years, that it will be allowed that, so far, observation and theory have gone along hand in hand. In a more distant future it may not be so. At present, theory has played its part in the refinement of observation, but some of the results of theory must for ever be removed from observational control. But just as the explorer of the earth's surface suggests to the geographer plans for further fruitful exploration, so the astronomer going to Nature with a definite theory may succeed in getting an answer. Finally, there can be no doubt that a great university should have an observatory as part of its equipment; but it must be recognised that the part of astronomy under these conditions necessarily has its limitations.

\section{Lachish}

Excavations at Tell Duweir in Palestine, where the Wellcome Historical Museum Expedition has been at work under Mr. J. L. Starkey, have now closed for the season. The particular interest of this excavation lies in the possibility that the site may be the city of Lachish which was captured by Joshua after a stout resistance. So far, nothing has been found to contradict this tentative identification, while some of the evidence from this season's work tends to confirm it. Lachish was captured by Sennacherib in 701 B.c.--this siege is represented on bas-reliefs from Nineveh now in the British Museum - and by Nebuchadnezzar in 586 B.c. Tell Duweir, which is situated about twenty-five miles south-west of Jerusalem at a height of $900 \mathrm{ft}$. above sea-level, dominating the Philistine country, is a mound of some forty acres in extent, tapering to eighteen acres at the summit. The stone walls identified with the city of Rehoboam show the breaches made by Sennacherib's army and traces of the conflagration by which they were made to collapse under Nebuchadnezzar. Under the stone walls of Rehoboam's city were found the red brick walls which are identified with the city of Joshua's day. A further piece of evidence pointing in the direction of the identification is the find of a metal helmet crest which corresponds with the crests on the peculiarly shaped helmets of some of Sennacherib's soldiers shown on the British Museum bas-reliefs. Part of a royal palace on the summit of the mound was uncovered, and a number of graves at the base belonging to all ages were examined and yielded a large number of skulls in excellent preservation. Objects from Tell Duweir will be on exhibition at the Wellcome Historical Museum, Euston Road, London, N.W.1, on their early arrival in England.

\section{National Research Council of Canada}

THE National Research Council of Canada has issued a statement covering its sixteen years work which indicates a close parallel between the activities of this Council and those of the Department of Scientific and Industrial Research in Great Britain. In addition to the direction of a wide range of investigations in a National Research Laboratories system, the development of a national library of science, and the publication of a Canadian Journal of Research, the Council has developed co-operation in research throughout Canada, instituted a policy of grants to individual research workers, and assisted in the training of scientific personnel by the award of scholarships to selected students and graduates. Its efforts have raised the whole standard of research in Canada and in addition the National Research Council has already proved its value in the day-today problems of government and to various State departments. During the sixteen years of its existence, the Council has paid a total of 527,951,000 dollars in research scholarships and 131,801,292 dollars in grants for research. More than half of the total expenditure has been incurred on the building and organisation of the National Research Labora. tories, which were formally opened on August 10, 1932, and have already made notable contributions to scientific knowledge and industrial development.

From a summarised account of these activities occupying nearly fifty pages, it is only possible to select a few points as illustrations. Important contributions to the asbestos industry have been rendered by investigations on asbestos cements and the standardisation of testing and methods. Studies of the resistance of concrete structures, the development of a highly resistant cement, of the treatment and disposal of sulphur dioxide fumes from smelter stacks, waste gas and bitumen utilisation, on the 